\title{
The need for artificial tears in glaucoma patients: a comparative, retrospective study
}

\section{O uso de lágrimas artificiais em pacientes com glaucoma: um estudo retrospectivo e comparativo}

\author{
Vital Paulino Costa $^{1}$, Renata Siqueira da Silva ${ }^{2}$, Renato Ambrósio Jr. ${ }^{2}$
}

\begin{abstract}
Purpose: To evaluate the need for artificial tears by glaucoma patients under topical hypotensive treatment and to identify risk factors associated with it.

Methods: The charts of 175 glaucoma patients under medical treatment and 175 age-matched controls were reviewed. Age, gender, use of artificial tears, number of glaucoma medications used, and duration of treatment were recorded.

Results: Significantly more glaucoma patients $(n=92 ; 52.6 \%)$ used artificial tears compared to age-matched controls $(n=31 ; 17.7 \%)(p<0.001)$. Significantly more females $(n=81 ; 39 \%)$ than males $(n=42 ; 28.9 \%)$ used artificial tears $(p=0.036)$. When the whole population was analyzed, female gender $(\mathrm{OR}=1.63)$ and the presence of glaucoma ( $O R=5.14)$ were risk factors for the use of artificial tears $(p<0.05)$. When the glaucoma population was analyzed, female gender $(\mathrm{OR}=2.57)$, number of medications $\geq 2(\mathrm{OR}=1.92)$, and duration of treatment $\geq 5$ years $(\mathrm{OR}=2.93)$ were risk factors for the use of artificial tears $(p<0.05)$.

Conclusions: Topical treatment with antiglaucoma medication is a risk factor for the use of artificial tears. Female gender and long-term treatment of glaucoma with two or more medications were aggravating factors for the need for artificial tears.
\end{abstract}

Keywords: Glaucoma; Ophthalmic solutions; Antihypertensiveagents/therapeutic use; Comparative study; Risk factors

\section{RESUMO}

Objetivo: Avaliar a necessidade do uso de lágrimas artificiais por pacientes com glaucoma recebendo tratamento medicamentoso e identificar fatores de risco associados ao seu uso.

Métodos: Os prontuários de 175 pacientes com glaucoma sob tratamento medicamentoso e de 175 controles pareados por idade foram revistos. Os seguintes dados foram registrados: idade, sexo, uso de lágrimas artificiais, número de medicações antiglaucomatosas e duração do tratamento do glaucoma.

Resultados: Um número significativamente maior de pacientes com glaucoma ( $n=92$; $52,6 \%)$ usava lágrimas artificiais em relação ao grupo controle $(n=31 ; 17,7 \%)(p<0,001)$. Um número significativamente maior de mulheres ( $n=81 ; 39 \%)$ usava lágrimas artificias em relação aos homens $(n=42 ; 28,9 \%)(p=0,036)$. Quando a população foi analisada como um todo, sexo feminino $(O R=1,63)$ e presença de glaucoma $(O R=5,14)$ foram fatores de risco para o uso de lágrimas artificiais $(p<0,05)$. Quando apenas a população de glaucomatosos foi analisada, número de medicações $\geq 2(O R=1,92)$ e duração do tratamento $\geq 5$ anos $(O R=2,93)$ foram fatores de risco para o uso de lágrimas artificiais $(p<0,05)$.

Conclusões: O tratamento com colírios antiglaucomatosos é um fator de risco para o uso de lágrimas artificiais. Sexo feminino e tratamento a longo prazo com duas ou mais medicações são fatores de risco adicionais para o uso de lágrimas artificiais.

Descritores: Glaucoma; Soluções oftálmicas/usoterapêutico; Anti-hipertensivos/uso terapêutico; Estudo comparativo; Fatores de risco

\section{INTRODUCTION}

Glaucoma is a chronic disease that frequently requires long-term treatment with topical ocular hypotensive eyedrops. The use of antiglaucoma medications has been associated with ocular surface disease (OSD) ${ }^{(1,2)}$, in part due to preservatives used in these medications ${ }^{(3)}$. Benzalkonium chloride (BAK), the most commonly found preservative in antiglaucoma medications, has been shown to decrease the stability of the precorneal tear film due to a detergent effect on the lipid layer and to a reduction in the density of goblet cells $s^{(4)}$.

Some authors ${ }^{(2)}$ applied the ocular surface disease index (OSDI), a validated questionnaire ${ }^{(5)}$ to investigate symptoms secondary to ocular surface disease, to 101 patients with open-angle glaucoma or ocular hypertension and reported that $59 \%$ of patients had scores compatible with ocular surface disease in at least 1 eye. Furthermore, they evaluated the tear break-up time in these patients and observed that $78 \%$ had abnormal tear quality in at least one eye. Recently, other authors $^{(1)}$ in a prospective multicentered observational study, applied the OSDI questionnaire to 630 glaucoma patients and found that $48.4 \%$ had scores indicative of mild $(n=134,21.3 \%)$, moderate $(n=84$, $13.3 \%)$, or severe $(n=87,13.8 \%)$ symptoms of OSD.

OSD may result in a myriad of ocular symptoms and signs, including burning/stinging, itching, foreign body sensation, tearing, and dry eye sensation ${ }^{(6,7)}$. When examined, patients with OSD typically present with variable levels of abnormal fluorescein and lissamine green staining of the cornea and conjunctiva, reduced tear break-up time, and an abnormal Schirmer's test ${ }^{(6,7)}$. Baffa et al. ${ }^{(8)}$ examined 21 patients with glaucoma and 20 age-matched controls and found that fluorescein and lissamine green staining were significantly more intense, and the tear break-up time was significantly reduced in the glaucoma group. Furthermore, several authors have suggested that OSD has a negative impact on the patients' quality of life ${ }^{(7,9)}$.

The initial approach to treat OSD relies on the use of artificial tears, although other options include omega-3 essential fatty acids, topical cyclosporine, anti-inflammatory agents, and lacrimal plugs ${ }^{(10-15)}$.
Submitted for publication: December 5, 2011

Accepted for publication: December 3, 2012

Study carried out Universidade de Campinas - UNICAMP, and Instituto de Olhos Renato Ambrósio. ${ }^{1}$ Physician, Setor de Glaucoma, Universidade Estadual de Campinas - UNICAMP - Campinas (SP), Brazil.

2 Physician, Instituto de Olhos Renato Ambrósio, Rio de Janeiro (RJ), Brazil.
Funding: This study was supported by Alcon Laboratórios do Brasil.

Disclosure of potential conflicts of interest: V.P.Costa, Board member non-remunerative of Alcon Labs and Merck, Sharp \& Dhome; Consultant of Alcon Labs and Merck, Sharp \& Dhome; Financial Support of Alcon Labs and Merck, Sharp \& Dhome; Recipient for Alcon Labs; R.S.da Silva, None; R.Ambrósio.Jr., Consultant for Alcon Labs; Recipient for Alcon Labs.

Correspondence address: Vital Paulino Costa. Rua Bahia, 1087 - Apto. 21 - São Paulo (SP) 01244-001 - E-mail: vp.costa@uol.com.br

Approved by Committee of Ethics in Research from Faculdade de Ciências Médicas, UNICAMP (0115.0.146.000-10 Sisnep). 
The purpose of this study is to evaluate the need for artificial tears among glaucoma patients under topical treatment, and to identify risk factors associated with it. We hypothesize that, since the use of antiglaucoma medication is associated with OSD, this may increase the necessity of artificial tears in these patients.

\section{METHODS}

This was a retrospective, comparative study approved by the Ethics Committee/Investigational Review Board of the University of Campinas, Brazil. The charts of 175 consecutive glaucoma patients and 175 age-matched ( \pm 2 years) controls followed at two private offices (VPC and RA) were reviewed. Both Institutions followed patients with glaucoma and patients without glaucoma.

The following characteristics were listed as inclusion criteria for the glaucoma group: diagnosis of glaucoma (primary open-angle, primary angle-closure, pigmentary glaucoma, or pseudoexfoliative glaucoma), and use of antiglaucoma medications. Patients included in the control group were followed for other ocular conditions, including refractive errors and cataract. Patients with previous intraocular surgery (i.e phacoemulsification, trabeculectomy, implant device, etc), previous laser surgery (except laser iridotomy), or use of contact lens were excluded from both groups. Patients previously diagnosed with dry eyes were not excluded from the study.

The following data was retrieved from the charts of both groups: age, gender, use of systemic drugs associated with dry eye (anti-histaminics, antidepressants, anti-hypertensives, cholinergic agents), use of artificial tears, use of topical cyclosporine, and insertion of lacrimal plug at the last examination. In the glaucoma group, we also evaluated the type of glaucoma, number and type of glaucoma medications, and duration of glaucoma treatment.

We compared the frequency of use of artificial tears in both populations using the Chi square or the Fisher exact test. We also investigated risk factors associated with the use of artificial tears in both groups and specifically in the glaucoma population applying the Cox-proportional hazard test. P values of less than 0.05 were considered statistically significant.

\section{RESULTS}

Table 1 lists the demographics of both populations. There were no significant differences regarding mean age, distribution of gender, or race between the groups ( $p>0.05)$. Most of the glaucoma patients had primary open-angle glaucoma (POAG) (82\%), and used one an-

Table 1. Demographics of both populations

\begin{tabular}{|c|c|c|c|c|c|}
\hline & \multicolumn{2}{|c|}{$\begin{array}{l}\text { Glaucoma } \\
\qquad=175\end{array}$} & \multicolumn{2}{|c|}{$\begin{array}{c}\text { Controls } \\
\mathrm{N}=175\end{array}$} & $\mathbf{P}$ \\
\hline \multicolumn{6}{|l|}{ Age (years) } \\
\hline Mean $\pm S D$ & \multicolumn{2}{|c|}{$66.6 \pm 13.0$} & \multicolumn{2}{|c|}{$64.3 \pm 13.8$} & \\
\hline Range & \multicolumn{2}{|c|}{$18-90$} & \multicolumn{2}{|c|}{$18-91$} & $0.11^{*}$ \\
\hline \multicolumn{6}{|l|}{ Gender } \\
\hline Male & 76 & $43.4 \%$ & 67 & $38.3 \%$ & \\
\hline Female & 99 & $56.6 \%$ & 108 & $61.7 \%$ & $0.38^{* *}$ \\
\hline \multicolumn{6}{|l|}{ Race } \\
\hline Caucasian & 154 & $88.0 \%$ & 155 & $88.6 \%$ & \\
\hline Mixed & 11 & $6.3 \%$ & 9 & $5.1 \%$ & \\
\hline Asian & 6 & $3.4 \%$ & 5 & $2.9 \%$ & $0.90^{* * *}$ \\
\hline African-american & 4 & $2.8 \%$ & 6 & $4.0 \%$ & \\
\hline
\end{tabular}

$\mathrm{SD}=$ standard deviation; ${ }^{*}=$ ANOVA $;{ }^{* *}=$ Chi Square test $;{ }^{* * *}=$ Fisher Exact test. tiglaucoma topical medication (55\%) (Table 2). Patients in the glaucoma group had been treated for a mean of $4.4 \pm 4.6$ years (range: 1 month to 38 years). Prostaglandin analogues alone (46\%) were used more frequently than other antiglaucoma medications. However, betablockers were also used by a large group of patients either alone (23\%) or in fixed combinations with other drugs (50\%).

Significantly more glaucoma patients $(n=92 ; 52.6 \%)$ used artificial tears compared to age-matched controls $(n=31 ; 17.7 \%)(p<0.001)$. Significantly more females $(n=81 ; 39 \%)$ than males $(n=42 ; 28.9 \%)$ used artificial tears $(p=0.036)$. When glaucoma patients and controls were analyzed as a whole, female gender $(\mathrm{OR}=1.63)$ and glaucoma diagnosis $(O R=5.15)$ were risk factors for the use of artificial tears (Table 3).

When the glaucoma group was analyzed separately, female gender remained a significant risk factor for the use of artificial tears $(\mathrm{OR}=2.57)$, along with the use of 2 or more antiglaucoma medications $(\mathrm{OR}=1.92)$ and duration of treatment greater than 5 years $(\mathrm{OR}=2.92)$. We could not establish a relationship between type of antiglaucoma medication and the need for artificial tears (Table 4).

\section{DISCUSSION}

Our findings confirm our hypothesis, i.e. that glaucoma patients present with a higher need for the use of more artificial tears than age-matched controls, which is in agreement with previous reports ${ }^{(1,2,16)}$. In a national panel survey, dry eye was found to be more common among glaucoma respondents than nonglaucoma controls (16.5\% vs 5.6\%, $\mathrm{P}<0.0001$ ), and there was a nonsignificant trend for glaucoma patients with dry eye to report higher rates of intraocular pressure-lowering medications than those without dry eye (44.2\% vs $35.0 \%, P<0.076)^{(16)}$. Interestingly, we found that the use of 2 or more antiglaucoma medications $(\mathrm{OR}=1.92)$ and duration of treatment greater than 5 years $(O R=2.92)$ were significantly associated with dry eye. We believe that this association is explained by the fact that longer treatments with more drops per day have a higher load of preservatives delivered to the ocular surface. Martone et al. ${ }^{(17)}$, in a comparative retrospective study using in vivo confocal microscopy,

\section{Table 2. Characteristics of the glaucoma population}

\begin{tabular}{lrc}
\hline & $\mathbf{N}=\mathbf{1 7 5}$ & $\%$ \\
\hline Type of glaucoma & 144 & 82.3 \\
POAG & 27 & 15.4 \\
PACG & 4 & 2.2 \\
Pigmentary glaucoma & & \\
Number of antiglaucoma medications & 96 & 54.9 \\
1 & 58 & 33.1 \\
2 & 17 & 9.7 \\
3 & 4 & 2.3 \\
4 & & \\
Type of antiglaucoma medication & 40 & 22.9 \\
Betablocker & 80 & 45.7 \\
Prostaglandin analogue & 25 & 14.3 \\
Carbonic anhydrase inhibitor & 18 & 10.3 \\
Alpha agonist & 31 & 17.7 \\
Fixed combination BB/PG & 48 & 27.4 \\
Fixed combination BB/CAl & 8 & 4.6 \\
Fixed combination BB/AA & & \\
\hline POAG Prima & & \\
\hline
\end{tabular}

$\mathrm{POAG}=$ primary open-angle glaucoma; $\mathrm{PACG}=$ primary angle-closure glaucoma; $\mathrm{BB}=$ betablocker; $\mathrm{CAl}=$ carbonic anhydrase inhibitor; $\mathrm{PG}=$ prostaglandin; $\mathrm{AA}=$ alpha agonist. 
Table 3. Univariate analysis of risk factors associated with the use of artificial tears including glaucoma patients and age-matched controls

\begin{tabular}{lccc}
\hline Variable & OR & $\mathbf{C l}$ & $\mathbf{P}$ \\
\hline Glaucoma & 5.148 & $3.16-5.89$ & $<0.001$ \\
Female gender & 1.632 & $1.03-2.58$ & 0.036 \\
Age $>50$ & 0.614 & $0.30-1.23$ & 0.887 \\
Race (Caucasian) & 0.629 & $0.32-1.22$ & 0.173 \\
Use of antidepressants & 0.876 & $0.43-1.76$ & 0.710 \\
Use of systemic BBs & 0.948 & $0.49-1.84$ & 0.876 \\
\hline
\end{tabular}

$\mathrm{BB}=$ betablocker; $\mathrm{OR}=$ odds ratio; $\mathrm{Cl}=$ confidence interval.

Table 4. Univariate analysis of risk factors associated with the use of artificial tears including only glaucoma patients

\begin{tabular}{lccc}
\hline Variable & OR & $\mathbf{C l}$ & $\mathbf{P}$ \\
\hline \# antigl. meds $>2$ & 1.924 & $1.14-3.24$ & 0.014 \\
Treatment $>5$ years & 2.929 & $1.39-6.17$ & 0.005 \\
Female gender & 2.569 & $1.39-4.74$ & 0.035 \\
Age $>50$ & 0.601 & $0.22-1.65$ & 0.325 \\
Race (Caucasian) & 0.513 & $0.19-1.34$ & 0.174 \\
Use of antidepressants & 0.539 & $0.17-1.71$ & 0.296 \\
Use of systemic BBs & 0.991 & $0.40-2.47$ & 0.985 \\
\hline
\end{tabular}

$\mathrm{BB}=$ betablocker; $\mathrm{OR}=$ odds ratio; $\mathrm{Cl}=$ confidence interval.

found lower density of superficial epithelial cells, higher density of basal epithelial cells, higher stromal keratocyte activation, less subbasal nerves and higher tortuosity on glaucomatous patients with chronic treatment. These significant ocular surface alterations were associated with clinical tests. One of the limitations of our study is that the data analyzed did not include specific tests for dry eye. However, even if this was a prospective study, defining dry eye (also recently termed dysfunctional tear syndrome) $)^{(18)}$ is still controversial. For example, some clinicians consider the diagnosis of dry eye only if decreased tear secretion or stability and ocular surface staining is documented, but there is a significant trend to consider the diagnosis based on symptoms as an early indicator of ocular surface disea$\mathrm{se}^{(6,13,19,20)}$. Also, there is no single objective method which is accepted to effectively detect the presence of dry eye.

Although a clinical diagnosis of dry eye was not possible in our series, it is likely that the majority of patients using artificial tears present with some degree of tear dysfunction, considering that the main indication of artificial tears is to relieve symptoms related to dry eye. Artificial tears administration in glaucomatous patients with dry eye also seems to improve significantly reliability parameters and visual field indices ${ }^{(21)}$. However, a study including a complete clinical examination of the ocular surface, including tear break-up time, ocular surface staining, Schirmer test, and eventually tear osmolarity is warranted.

We also identified female gender, number of antiglaucoma medications and duration of glaucoma treatment as risk factors for the need of artificial tears. Female gender has been listed as a risk factor for dry eye ${ }^{(13,20)}$. Other studies have also reported number of antiglaucoma medications as a risk factor for dry eye. Fechtner et al. ${ }^{(1)}$, observed that the mean OSDI score significantly increased from 12.9 when one antiglaucoma medication was used to 19.4 when three or more medications were used $(p=0.0001)$. Other authors ${ }^{(22)}$ investigated the occurrence of dry eye syndrome (defined as presence of punctuate keratitis or decreased tear break-up time) in 61 glaucoma patients divided according to the number of glaucoma drops instilled per day $(1,2$, or 3$)$. The prevalence of dry eye was $40 \%$ in patients using 3 drops/day, 39\% in patients using 2 drops/day, and $11 \%$ in patients using one drop/day. Furthermore, OSDI questionnaires revealed that $15 \%$ of those using 3 drops/day and $8.7 \%$ of those using 2 drops/day showed severe OSD. Finally, Pisella et al. ${ }^{(4)}$, observed that the prevalence of ocular symptoms and signs related to dry eye were dose dependent, increasing with the number of preserved antiglaucoma drops.

Although there is some evidence that glaucoma per se may be associated with decreased basal tear turnover ${ }^{(23)}$, most of the studies blame the development of dry eye on the chronic use of antiglaucoma medications, especially due to the presence of preservatives. It is conceivable that the effects of toxic preservatives on the ocular surface are cumulative, which explains why duration of treatment $>5$ years was also a risk factor for the use of artificial tears in our series. The most frequently used preservative, BAK, is a quaternary ammonium that causes tear film instability, loss of goblet cells, conjunctival metaplasia and apoptosis, and disruption of the corneal epithelial barrier, which leads to greater penetration of the drug in the anterior chamber ${ }^{3}$. Several studies have compared ocular surface symptoms and signs in patients using preserved vs. non-preserved eyedrops and all of them indicate that the use of preservative-free eye drops is associated with reduced ocular side effects ${ }^{(24,25)}$

Interestingly, some of our patients were using artificial tears containing BAK as a preservative, which would theoretically worsen the ocular surface condition. It is important to emphasize that patients with OSD secondary to the chronic use of antiglaucoma medications should be preferably treated with preservative-free artificial tears. The use of plugs to decrease tear flow should be used with caution in these patients, since there is a possibility of increasing the contact between the preservative and the ocular surface.

\section{CONCLUSION}

Our study demonstrates that female gender and long-term treatment of glaucoma with two or more medications may increase the need for artificial tears. The development of preservative-free antiglaucoma medications or medications with less toxic preservatives (26) is likely to benefit patients, reducing ocular surface changes ${ }^{(17)}$ and possibly improving their quality of life.

\section{REFERENCES}

1. Fechtner RD, Godfrey DG, Budenz D, Stewart JA, Stewart WC, Jasek MC. Prevalence of ocular surface complaints in patients with glaucoma using topical intraocular pressure-lowering medications. Cornea. 2010;29(6):618-21.

2. Leung EW, Medeiros FA, Weinreb RN. Prevalence of ocular surface disease in glaucoma patients. J Glaucoma. 2008;17(5):350-5

3. Baudouin C, Labbe A, Liang H, Pauly A, Brignole-Baudouin F. Preservatives in eyedrops: the good, the bad and the ugly. Prog Retin Eye Res [Internet]. 2010 [cited 2012 Jun 12];29(4):312-34. Available from: http://www.sciencedirect.com/science/article/ pii/S1350946210000157

4. Pisella PJ, Fillacier K, Elena PP, Debbasch C, Baudouin C. Comparison of the effects of preserved and unpreserved formulations of timolol on the ocular surface of albino rabbits. Ophthalmic Res [Internet]. 2000[cited 2012 Mar 10]32(1):3-8. Available from: http://www.karger.com/Article/FullText/55579

5. Schiffman RM, Christianson MD, Jacobsen G, Hirsch JD, Reis BL. Reliability and validity of the Ocular Surface Disease Index. Arch Ophthalmol [Internet]. 2000[cited 2010 Nov 21];118(5):615-21. Comment in: Arch Ophthalmol. 2001;119(3):456. Available from: http://archopht.jamanetwork.com/article.aspx?articleid=413145

6. The definition and classification of dry eye disease: report of the Definition and Classification Subcommittee of the International Dry Eye WorkShop (2007). Ocul Surf 2007:5(2):75-92.

7. Tavares F de P, Fernandes RS, Bernardes TF, Bonfioli AA, Soares EJ. Dry eye disease. Semin Ophthalmol. 2010;25(3):84-93.

8. Baffa L do P, Ricardo JR, Dias AC, Módulo CM, Braz AM, Paula JS, et al. Tear film and ocular surface alterations in chronic users of antiglaucoma medications. Arq Bras Oftalmol [Internet]. 2008 [cited 2010 Oct 21];71:18-21. Available from: http://www. scielo.br/pdf/abo/v71n1/v71n1a04.pdf

9. Garcia-Catalan MR, Jerez-Olivera E, Benitez-Del-Castillo-Sanchez JM. [Dry eye and quality of life]. Arch Soc Esp Oftalmol [Internet]. 2009 [cited 2010 Jun 21]; 84(9):451-8. 
Spanish. Available from: http://www.oftalmo.com/seo/archivos/maquetas/F/350 415A1-04F3-FF09-73C4-000049E3D6EF/articulo.pdf

10. Rosenberg ES, Asbell PA. Essential fatty acids in the treatment of dry eye. Ocul Surf 2010;8(1):18-28.

11. Ervin AM, Wojciechowski R, Schein O. Punctal occlusion for dry eye syndrome. Cochrane Database Syst Rev [Internet]. 2010 [cited 2011 Aug 25];8(9):CD006775. http:// onlinelibrary.wiley.com/doi/10.1002/14651858.CD006775.pub2/full

12. Donnenfeld E, Pflugfelder SC. Topical ophthalmic cyclosporine: pharmacology and clinical uses. Surv Ophthalmol [internet] 2009[cited 2012 Jun 21];54(3):321-38. Comment in: Surv Ophthalmol. 2010;55(2):189. Available from: http://www.sciencedirect. com/science/article/pii/S003962570900037X

13. Abelson MB, Ousler GW $3^{\text {rd }}$, Maffei C. Dry eye in 2008. Curr Opin Ophthalmol. 2009; 20(4):282-6.

14. Ambrosio R Jr, Tervo T, Wilson SE. LASIK-associated dry eye and neurotrophic epithe liopathy: pathophysiology and strategies for prevention and treatment. J Refract Surg. 2008;24(4):396-407

15. Fonseca EC, Arruda GV, Rocha EM. [Dry eye: etiopathogenesis and treatment]. Arq Bras Oftalmol [Internet]. 2010[cited 2012 Jun 21];73(2):197-203.Portuguese. Available from: http://www.scielo.br/pdf/abo/v73n2/v73n2a21.pdf

16. Schmier JK, Covert DW. Characteristics of respondents with glaucoma and dry eye in a national panel survey. Clin Ophthalmol [Internet] 2009[cited 2010 Dec 21]:3:645-50. Available from: http://www.ncbi.nlm.nih.gov/pmc/articles/PMC2788591/

17. Martone G, Frezzotti P, Tosi GM, Traversi C, Mittica V, Malandrini A, et al. An in vivo confocal microscopy analysis of effects of topical antiglaucoma therapy with preservative on corneal innervation and morphology. Am J Ophthalmol. 2009;147(4):725-35e1.

18. Behrens A, Doyle JJ, Stern L, Chuck RS, McDonnell PJ, Azar DT, Dua HS, Hom M, Karpecki PM, Laibson PR, Lemp MA, Meisler DM, Del Castillo JM, O'Brien TP,Pflugfelder SC Rolando M, Schein OD, Seitz B, Tseng SC, van Setten G, Wilson SE, Yiu SC; Dysfunctional tear syndrome study group. Dysfunctional tear syndrome: a Delphi approach to treatment recommendations. Cornea. 2006;25(8):900-7. Comment in: Cornea. 2007; 26(7):901.

19. Dogru M, Stern ME, Smith JA, Foulks GN, Lemp MA, Tsubota K. Changing trends in the definition and diagnosis of dry eyes. Am J Ophthalmol 2005;140(3):507-8.

20. Herrero-Vanrell R, Peral A. [International Dry Eye Workshop (DEWS). Update of the disease]. Arch Soc Esp Oftalmol [Internet]. 2007[cited 2009 Aug 21];82(12):733-4. Spanish. Available from: http://www.oftalmo.com/seo/archivos/maquetas/F/388144 D4-E886-0149-62B8-00003843D50F/articulo.pdf

21. Yenice $O$, Temel A, Orum O. The effect of artificial tear administration on visual field testing in patients with glaucoma and dry eye. Eye (Lond) [Internet]. 2007[cited 2010 Nov 21];21(12):214-7. Available from: http://www.nature.com/eye/journal/v21/n2/ full/6702252a.html

22. Rossi GC, Tinelli C, Pasinetti GM, Milano G, Bianchi PE. Dry eye syndrome-related quality of life in glaucoma patients. Eur J Ophthalmol. 2009;19(4):572-9.

23. Kuppens EV, van Best JA, Sterk CC, de Keizer RJ. Decreased basal tear turnover in patients with untreated primary open-angle glaucoma. Am J Ophthalmol. 1995;120(1): 41-6.

24. Jaenen N, Baudouin C, Pouliquen P, Manni G, Figueiredo A, Zeyen T. Ocular symptoms and signs with preserved and preservative-free glaucoma medications. Eur J Ophthalmol. 2007;17(3):341-9.

25. Uusitalo $H$, Chen E, Pfeiffer N, Brignote-Baudouin F, Kaamiranta K, Leino $M$, et al. Switching from a preserved to a preservative-free prostaglandin preparation in topical glaucoma medication. Acta Ophthalmol [Internet]. 2010 [cited 2012 Sep 15]; 88(3):329-36. Available from: http://onlinelibrary.wiley.com/doi/10.1111/j.1755-3768. 2010.01907.x/pdf

26. Ammar DA, Noecker RJ, Kahook MY. Effects of benzalkonium chloride-preserved, polyquad-preserved, and sofZia-preserved topical glaucoma medications on human ocular epithelial cells. Adv Ther [Internet]. 2010 [cited 2012 Oct 15];27:837-45. Available from: http://link.springer.com/article/10.1007\%2Fs12325-010-0070-1 